\title{
Evaluation of Sustainability of the General Government Debt in a Small Open Economy
}

\author{
Prof. Dr. Vytautas Snieska
}

Kaunas University of Technology, Lithuania, Vytautas.Snieska@ktu.It

\author{
Dr. Aura Draksaite
}

Kaunas University of Technology, Lithuania, Aura.Draksaite@ktu.It

\author{
Doi:10.5901/mjss.2013.v4n9p610
}

\begin{abstract}
As borrowing conditions and economy of indebted small open countries usually highly depend on changes in international financial markets and considering the vulnerability of their economy to stochastic changes of the global economy, such countries usually are exposed to relatively higher rate of borrowing-induced risk in comparison with big open economy countries. Indebted country with no capability to maintain sustainable government debt risks boosting its debt to such extent that would cause long term damage to its economy. However, one of the common problems, remaining in the contemporary economy, is the determination whether general government's debt is sustainable or not. Results of such evaluation would help to determine the effectiveness of the debt management strategy of the country. The aim of the paper is to reveal the peculiarities of evaluation of sustainability of the general government debt in a small open economy.In the paper, peculiarities of borrowing of small open economy countries are briefly discussed. The most common methods of evaluation of the sustainability of government debt are presented. The general shortages, advantages and limitations of some basic evaluation methods are pointed out. Challenges to maintain sustainability of general government's debt in small open economy countries are revealed. Example of Lithuania's government borrowing and debt management is given. The main research methods employed in the paper are the following: systemization, generalization and logic analysis of scientific sources of information; quantitative, qualitative and comparative analysis of the data, case study, graphic presentation of the data and results. The paper concludes with the findings describing the main results of the research and patterns that could be followed when evaluating the sustainability of the general government debt in a small open economy country.
\end{abstract}

Keywords: general government debt, sustainable debt, Lithuania's debt, debt evaluation.

\section{Introduction}

In the contemporary global economy, government of the most countries borrow abroad and in their own market. For these governments borrowing is one of the most common ways to finance the economic needs of their countries. Benefits and downside of general government's borrowing are widely discussed in the scientific economic literature. For example, the impact of government's borrowing on the country's economy is examined by Moinescu (2013), Faraglia et al. (2013), Legrenzi and Milas (2012), Ryskulov and Mera (2012), von Wijnbergen and France (2012), Taylor et al. (2012), Eggertsson and Krugman (2012), Molănescu and Aceleanu (2011), Aspromourgos et al. (2010), Liliko et al. (2009), Neck and Sturm (2009), Karazijiene (2009). Although general government's borrowing often is beneficial for the economy of the country, borrowing also causes the increase of its debt.

If uncontrollably increasing, government's debt can lead to a situation where the government is unable to repay the debt or borrow again. This can cause the prolonged economic recession of the country. In most cases, as a result of the economic recession, there is not only an increase in government borrowing costs, but also in their borrowing needs, which further complicates the economic situation in the country.

Therefore sustainable borrowing can be considered as one of the prerequisites for the sustainable economic growth of the country or economic union.

Government of a small open economy usually faces even more complex borrowing environment than the one of a big open economy. This is caused mainly by the higher economic vulnerability of small open economies. If compared to large countries, countries of small open economy usually are more sensitive to changes of interest rates and international economic. In case of sudden adverse economic changes, they usually face relatively higher economic losses due to the increased and "more expensive" debt than large economies. Especially this is evident if such economy has high debt 
rate. This tendency is demonstrated even more explicitly in case of economic recessions. Therefore, in order to achieve sustainable economic growth of economy and given the small open economy's sensitivity to interest rate changes and to stochastic changes in the global economy, also considering the impact of these factors on the change of general government's debt, the borrowing policy of general government of small open economy should be based on sustainable borrowing.

In this article we examine only those countries that do not use any other measures to adjust the level of their general government's debt apart from using effective borrowing.

As the first step towards sustainable management of general government debt is the evaluation of the existing debt, the aim of the paper is to reveal the peculiarities of evaluation of sustainability of the general government debt in a small open economy.

Various government debt sustainability assessment methodologies are considered by Faraglia et al. (2013), Teica (2012), Choi et al. (2010), Hajdenberg and Romeu (2010), Frank and Ley (2009), Neck and Sturm (2009), Sopek (2009), Genberg and Sulstarova (2008), Wyplosz (2007), Telatar et al. (2004), Uctum ir Wickens (2000). In general, in scientific literature there is no consensus, what are the government's debt sustainability criteria and assumptions for sustainable debt. Various authors provide very different and distinct concepts of government debt sustainability and assumptions for government debt sustainability. Also, the importance of the stochastic nature of the economy and the peculiarities of small open economy's borrowing is often underestimated.

In the article, first, the concept of general government debt and its sustainability is briefly described. Then, most common generalized basic peculiarities of borrowing of small open economy countries are discussed. Considering this, peculiarities of evaluation of sustainability of the small open economy's general government debt are discussed. The most common methods of evaluation of the sustainability of government debt are presented. The general shortages, advantages and limitations of some basic evaluation methods are pointed out. Challenges to maintain sustainability of general government's debt in small open economy country are revealed. Example of Lithuania's government borrowing and debt management is given.

The main research methods employed in the paper are the following: systemization, generalization and logic analysis of scientific sources of information; quantitative, qualitative and comparative analysis of the data, case study, graphic presentation of the data and results.

The paper concludes with the findings describing the main patterns that could be followed when evaluating the sustainability of the general government debt in a small open economy country.

\section{The concept of the general government's debt and its sustainability}

In this article we use the term "general government" as it is described by the statistical office of the European Union Eurostat. According to Eurostat, general government comprises the following subsectors: state government (where applicable), central government, local government, social security funds (http://epp.eurostat.ec.europa.eu/ statistics_explained/index.php/Structure_of_government_debt\#General_government). Similar definition of general government sector is given by the International Monetary Fund (IMF): "the general government sector comprises all government units and all nonmarket non-profit institutions (NPIs) that are controlled by government units" (Public sector debt statistics, 2011).

In general, the general government's debt can be explained as a whole of unpaid government debts, which can be defined by an adequate amount of money. In many cases, the general government's debt also can be described as one incurred by country's highest executive authority or a central government, which is authorized to work on behalf of the state. As suggested by the IMF, debt can be explained as a whole of all liabilities that are debt instruments, i.e. financial claims that require payment(s) (Public sector debt statistics, 2011).

There are different definitions of the sustainable government debt, covering different aspects of it. Usually, government's borrowing strategy is considered neither efficient nor sustainable if government is overspending and no additional value is created for the future generations, which will have to cover costs of the present borrowing. Likewise, a level of debt can be defined as "sustainable" if the main macroeconomic indicators of the country remain steady or show economic growth over the long-run (Rankin \& Roffia, 1999). IMF suggests the following definition of debt sustainability: a debt "is sustainable if it satisfies the solvency condition without a major correction [...] given the costs of financing" (Wyplosz, 2007).

In our opinion, general government's debt can be described as sustainable if the strategy of borrowing and debt management results in meeting the general government's borrowing demands and, at the same time, does not 
negatively affect credit solvency of the general government and economic stability of the country in the long-run. In our opinion, one of the most important prerequisites for sustainable general government's debt is the government policy's orientation towards a sustainable development of the economy. Also, we presume that important prerequisites are: the competency of the government borrowing strategy developers and the debt administrators, who should be capable of making the necessary decisions on time and evaluation of the debt-associated risks under the stochastic nature of economy; a sufficient generation of the funds for debt repayment; the conditions for necessary structural reforms in the country; an effective use of the borrowed funds.

It is important for the most countries of the world to maintain general government's debt sustainable, but it is critically important for the small open economy countries with relatively high level of indebtedness. In our opinion, this is mostly because of their dependency on the global economy and vulnerability to its changes. Non-sustainable management of the general government's debt can cause the lowering of credit ratings, as well as reduction of the borrowing possibilities, country's economic recession, crisis, stagnation or even bankruptcy of the country. Nonsustainable general government's debt can also cause an uncontrolled growth of the debt, decrease of the solvency of a government or a country, increase in the borrowing and debt service costs, increase of the country's budget deficit, decrease in the productivity of manufacturing due to lack of investments. Also, if high level of debt is owed to the foreign creditors, there is a danger to loose political independence of the country. In a small open economy country with nonsustainable general government's debt management, such consequences can be caused by adverse changes in the international financial market or by a sudden, unexpected economy recession.

On the other hand, sustainability of general government's debt helps to maintain the sustainability of economic development and increases financial stability of the country. Also, sustainable government debt can cause the decrease of the country's budget deficit or increase of the budget surplus. The creditworthiness of a country usually is higher if the general government's debt is sustainable and this allows borrowing the sufficient amount of money (relatively cheap) for the effective development of country's economy.

Thus the sustainability of the general government's debt is important for the sustainable growth of the country's economy. Therefore, it is essential for the most country of the world to be able to evaluate the sustainability of the general government's debt accurately. Based on the evaluation, further decisions concerning measures to increase the sustainability of the debt (if such increase is necessary) can be considered.

\section{Peculiarities of the small open economy's general government borrowing}

In this article we examine only those countries that do not use any other measures to adjust the level of their general government's debt apart from using effective borrowing.

An open economy is usually described as market economy where export's and import's ratio to GDP is relatively big (Pisani, 2011; Down, 2007; Telatar et al., 2004; Edwards, 1993; etc.). Open economy participates in international trade to a comparatively great extent and is open to international investment. A closed economy neither borrows from nor lends to foreign countries or economies. The openness of a country's economy provides countries with an opportunity to get additional financing by borrowing from foreign financial markets. Thus, country's economy growth is positively stimulated.

In this article, small economy is considered as economy, change of which does not significantly affect the global economy (or have practically no affect on it). Usually, a large and rising share of national product in small open countries can also be directly linked to international trade in goods and services, which makes small open countries highly vulnerable to changes in international economy.

Respectively, government debt managers in small open economies are generally facing greater and more complex borrowing-related risks (particularly, when managing their foreign debt and executing debt financing strategies) in comparison with their counterparts, managing debt in countries of large open economy.

Yet, size of the economy does not influence the efficiency of it (Down, 2007; Raimondos-Moller \& Woodland, 2000). Debt level of a small open economy does not depend directly on the size of the country's economy as well. Therefore, the sustainability of the general government's debt basically depends on the effectiveness of the borrowing policy.

Small open economy, being "price-taker" in the global market, practically can not affect global interest rates (Mankiw, 1997). With reference to the suggested definition of a small economy, a small open economy also could be described as one who does not alter world prices or incomes. For both large and small open economies, world real interest rate is the same. The difference occurs because of domestic interest rate and often because of the ability to 
influence the interest rate. Principle scheme of foreign lending-borrowing between large and small open economies is shown in Fig. 1.

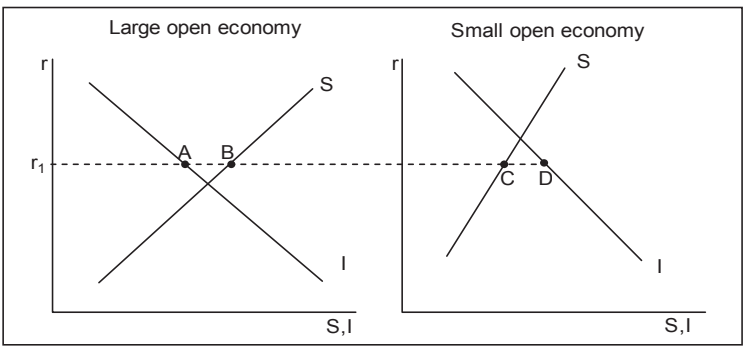

Figure 1. Principle scheme of foreign lending-borrowing

As shown in Fig. 1, if the real interest rate in large economy is $r_{1}$, it can lend amount of $A B$, and small economy can borrow amount $C D$. Equilibrium occurs if $A B$ equals to $C D$.

Small and very open countries' economic sensitivity to global economic development is extremely high. When taking a loan or borrowing in international market, small countries with open economies are forced to accept the interest rate, set in that particular market. The changes in the international finance market directly influence borrowing possibilities of the small open economy countries. This becomes particularly obvious during the periods of a sudden economic downturn or the economic crisis, when general government's debt can increase uncontrollably or even cause bankruptcy of the country due to the lack of sustainability of the general government's debt. Also small open economy often has little of prevention measures against the unfavourable changes in global finance market. Therefore, in case of such changes of economy, recovery processes in small open economy are much more slowly than in countries with large open economy.

Furthermore, fundraising from abroad is also often difficult for small countries because such economies are often considered to be of relatively higher risk in comparison to large economies. Many small open economies also are not in the position to benefit from efficient international risk-sharing arrangements (Garcia \& Rigobon, 2004).

Therefore, when borrowing, general government of small open economy should evaluate the stochastic nature of the economy and implement means, which allow increasing the sustainability of general government debt. The perception of uncertainty factor as the concurrent component in development of contemporary strategies of general government's debt management is becoming common sense. Especially this should be applicable for countries with developing financial markets, as the wrong borrowing strategy can result in crisis of economy or even bankruptcy of the country. The cost of not hedging the risk of interest rate change is of the extent of losses caused by this risk. General government of a small open economy should consider the sustainability of borrowing as a strategic goal.

As discussed, stochastic nature of the global economy increases volatility of the small open economy. In this regard, risk management measures can be used to increase the sustainability of the general government's debt. Such means allow controlling of the debt level and prevent against economic loss in case of adverse changes in borrowing market. Although these means are relatively expensive, economic benefit of using them is obvious. Nevertheless, tradeoff between borrowing costs and benefit of the sustainable borrowing should be considered at all times.

To some degree, structure of the general government debt obligations in small open economies also should be considered more carefully than in large economies, because it is argued that structure of the debt has influence on the sustainability of the debt (Melecky, 2012; Consiglio \& Staino, 2012; Date et al., 2011). For instance, it is argued that the higher the share of short-term credit is in overall debt, the larger and more vulnerable is the annual flow of debt-service obligations. For example, in Lithuania, which can be considered a small open country (according to described criterions of small open economy), in period of years 2004-2011 averagely 89,03 \% of overall government debt was long-term credit. Currency of the debt also can be examined in this regard. Small open countries often are borrowing in foreign currencies, which is not the case for the major or more closed economies, e.g. the United States of America is considered to have the deepest and most liquid debt markets, and Japan largely finances its debt domestically (Roubini \& Bykere, 2010). Stabile currency exchange rate increases the sustainability of the general government's debt. Also, depending on specific situation, and considering that often small economy has limited domestic financial market, the ratio between domestic and foreign debt can be considered as indicator of higher debt-associated risk.

In addition, many countries with small open economy have slender financial capabilities and limited resources. Often one of the most important prerequisites of development in those countries is implementation and exploitation of the 
advanced knowledge. Thus, it is vital for governments of small open economies to manage the government debt with eminent caution, employing the most advanced methods in this field.

Considering the peculiarities of the small open economy's general government borrowing and the concept of sustainable general government debt, evaluation of the sustainability of general government's debt in a small open economy can be performed. Evaluation must be based on qualitative and quantitative examination of the specifics (specific economic environment, specific debt management conditions etc.) of each and every case.

\section{Evaluation of the sustainability of general government's debt in a small open economy}

The sustainability of general government's debt is often evaluated by taking into account the retrospective dynamics of certain statistical indicators (Goldstein, 2010; Izák, 2009; Presbitero \& Arnone, 2006). Considering the stochastic nature of the economy, these methods are not suitable for the evaluation of the sustainability of general government's debt in a small open economy.

As already discussed, sometimes solvency of the general government is evaluated in respect of the debt structure peculiarities (Melecky, 2012; Consiglio \& Staino, 2012; Date et al., 2011; Milne, 2011; Choi et al., 2010). Lately, however, it is increasingly recognized that in applied economic and financial models, the accuracy of the results is strongly influenced by the use of stochastic variables (Consiglio \& Staino, 2012; Date et al., 2011; Hajdenberg \& Romeu, 2010; Frank \& Ley, 2009; Ciegis et al., 2009; Ferrarini, 2009; Budina \& van Wijnbergen, 2009; Ferrarini, 2008; Tanner \& Samake, 2008; Genberg \& Sulstarova, 2008) and complex analysis of debt indicators (Knedlik \& Von Schweinitz, 2012; Sopek, 2009). These methods are increasingly being used as an effective tool to assess and predict the debt-related risk. But methods, considering stochastic nature of the economy, are extensively being used for evaluation of sustainability of general government debt only in the last decade. However, in current economics, stochastic nature of economy is not always taken into the consideration when evaluating the strategy of general government's borrowing in small open economy.

Considering the basis for evaluation of the sustainability of the general government's debt, it can be considered, that the general government's debt management strategy is not sustainable if, over long-run, the indebtedness of the general government has significantly increased - or such increase is likely to occur in the nearest future - and the marginal debt service costs are escalating. Also, strategy of the general government's debt management can not be considered as sustainable if, over long-run, general government is no longer able to meet its debt obligations. For example, during period of 2004-2012 year, average rate of central debt growth was 2,25 times higher than the average rate of GDP growth. But, as it will be argued further on, no conclusions regarding sustainability of the general government's debt, based solely on this indicator, can be made.

Generally, the evaluation methods used for the evaluation of sustainability of the general government debt can be grouped in two broad groups - quantitative and qualitative evaluations. Econometric calculations are mostly used in quantitative measurements and contingent variables are analyzed in qualitative evaluations. The latter is especially important for the sustainability of the general government debt and the economy on the whole, because it allows taking the stochastic aspects of the economy into account. However, these methods can be very different considering the chosen variables, evaluation approach, time span etc. Nevertheless, most of these methods have one common feature they are evaluating more than twenty variables as a complex.

Complex analysis of the general government's debt sustainability factors better indicate the sustainability or lack of it. Therefore, lately, in order to estimate the sustainability, models, allowing a complex assessment of the debt, are used more extensively. In relevance of the concept of debt sustainability, other main methods for evaluation of the sustainability of the general government debt are: evaluation of debt-associated risk management; evaluation of borrowed fund usage; evaluation of debt level, interest or debt servicing cost level etc.; evaluation of debt structure; evaluation of fiscal or/and monetary policy etc. The basis of the sustainability of a general government's debt portfolio should be complex analysis of the factors, influencing the debt sustainability. Such analysis must be based on the usage of stochastic methods.

The changes in global markets directly influence the economy of relatively very open and indebted small open countries. Their sensitivity to the global economic changes is particularly high. Therefore, before borrowing, general government of a small open economy should properly evaluate the possible unexpected unfavourable changes in the international market.

There are many conceptions, according to which the sustainability of general government's debt can be estimated. The ratio of the debt to GDP or its dynamics, widely used by many economists and politicians, does not actually reflect 
the sustainability of a general government's debt. The sustainability of the government debt is also often associated with the solvency of a debtor. Considering the concept of debt sustainability, we have established that the main methods, used to evaluate the sustainability of general government's debt, are the following: evaluation of risk management; evaluation of debt-associated risk; evaluation of government's solvency; evaluation of borrowed fund usage; evaluation of debt level, cost level etc.; evaluation of government debt portfolio structure; evaluation of fiscal or/and monetary policy.

Employment of contingency factor is one of the essential steps of the evaluation of sustainability of general government debt, suggested by IMF (Wyplosz, 2007). According to IMF, as historical correlations are not necessary to be relevant in the future, it is reasonable to take into account all the estimated correlations and to generate all the possible combinations of shocks. The procedure can be automated to randomly generate a very large number of shocks, literally thousands of them, small and big, isolated and combining many events. Crucially, the method associates each shock with a probability of occurrence. It provides association of each shock with the corresponding variation of the debt and calculates the probability of its occurrences (Monte Carlo simulations). In addition, IMF also suggests stress testing, as a mean, for example, to estimate the volatility of the existing debt management strategy.

Considering their characteristics, small open economies lack the natural stabilizing factors that allow the use of effective policies against the unfavourable changes in international finance market. Also the risk of economic crisis or even bankruptcy of the country in case of inefficient borrowing is higher for small open economy countries than for large economy countries. For example, Lithuania is highly dependant on international borrowing markets, because its foreign debt is much bigger than domestic debt. In period of year 2004-2011, ratio of Lithuania's central government foreign debt to its total debt was averagely $71,44 \%$, and was averagely 2,5 times bigger than domestic debt. Therefore, small open economies should be much more cautious about those tools of management of foreign debt that enable decision makers to avoid or at least mitigate the possible economic loss in case of unexpected changes of international economy.

The sustainability of a debt should be constantly monitored, and the borrowing costs should be constantly compared with the benefits of borrowing. Also, it is important that the evaluation of the sustainability of the general government's debt should be performed considering specifics of the country/economy.

We have performed the respective extensive evaluation of the sustainability of Lithuania's central debt, which in period of 2004-2012 years made averagely 93,93\% of the general government's debt, and therefore plays the major role in Lithuania's general government's debt. The evaluation has been performed using different discussed approaches of the evaluation of the sustainability of general government's debt in a small open economy. Evaluation period was chosen to be period from year 2004 to year 2011 or 2012 (depending on data availability). Year 2004 has been chosen because it is the year when Lithuania has joined the EU, and therefore many aspects of general government's debt management have changed. Due to the article's volume limitations, we are not able to discuss the whole evaluation methodology or the detailed results, but further in the article we provide some of the main results of the evaluation.

The main economic shock during this period was the world financial crisis, which allowed better demonstration of the (non-)sustainability of the general government's debt.

A sudden increase of the debt in year 2009 was mainly caused by the fact that during the period of the financial crisis, the borrowing was relatively expensive, the borrowing costs were relatively higher, and the credit rating was lower. Fig. 2 shows the dynamics of the ratio of central government debt to GDP and the dynamics of the ratio of government's net borrowing to GDP during period of 2004-2011 years.

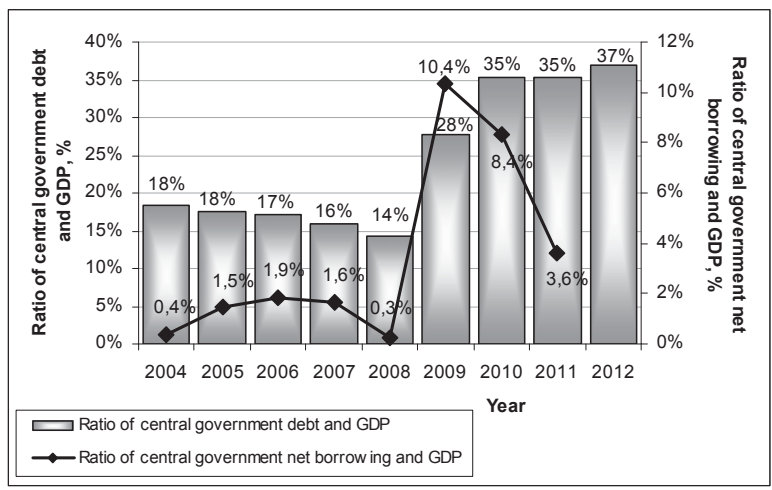

Fig. 2. The dynamics of central government debt and the dynamics of net borrowing ratio to GDP in year 2004-2011 
Fig. 2 shows that although ratio of central government debt to GDP is increasing from year 2009, ratio of central government's net borrowing to GDP after the financial crisis of the world is decreasing.

Considering the debt-associated risk, in Lithuania there is no risk of changes in exchange rate. In Lithuania, using derivative financial means, at the end of year 2008 99,99\% of the general government's debt was denominated in Euros and Litas, and since year 2009 100\% of debt liabilities of general government is only in Euros and Litas. The risk of interest rate changes is a minor threat to the sustainability of the Lithuanian government's debt, as the major part of the debt has fixed interest rates. According to the results of the evaluation, the risk of liquidity (refinancing) is considered to be the biggest threat (in relevance to manageable risks). We argue that debt-associated risk costs should be considered in regard to the possible economic loss due to the non-hedging.

Assessing the sustainability of the central government debt as an ability to meet the financial obligations, given the calculated ratio of the central government's debt to GDP, and having assumed that the increase of the ratio of the debt to GDP will not change, the central government's debt can be considered sustainable. However, evaluating the sustainability at this respect, the central government's debt can be considered sustainable only in case if the rate of GDP increase will exceed the rate of the debt increase (the situation until the global financial crisis of year 2008-2009).

Also, we discovered that during year 2004-2012, rate of the central government debt increase was higher than rate of the debt management costs. In this regard, the central government's debt can be considered sustainable if the tendencies of the change of debt management cost remain the same or the cost starts to decrease.

According to the results of our research, it can be assumed that the most significant influence on the sustainability of the central government's debt during the period of year 2004 - 2011 was made by the increase of debt cost due to the global financial crisis, and rather not due to the debt management decisions. It was established that interest cost is the main factor, causing the increase of the deficit of the central government (Fig. 3).

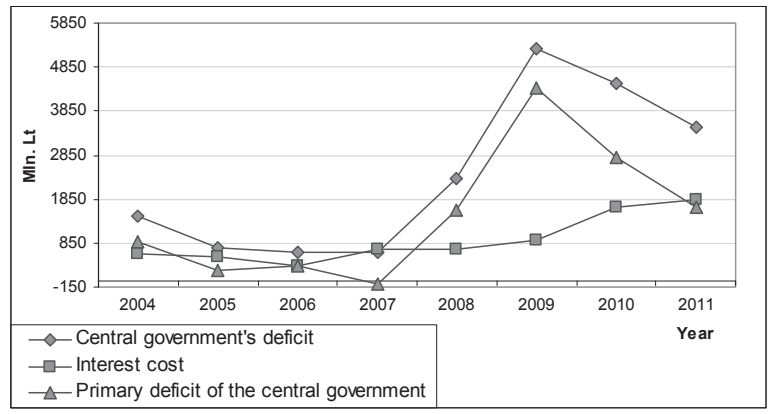

Fig. 3. The dynamics of central government's debt, interest cost and the primary deficit of the central government in year 2004-2011

However, the risk of interest rate changes is not a major threat to the sustainability of the Lithuanian general government's debt, as the major part of the debt has fixed interest rates (averagely $96,49 \%$ of all general governmet's debt liabilitys during period of year 2004-2011 have fixed interest rates).

In general, we assume that borrowing and management of Lithuanias's general government debt is based on the relevant sustainability principles.

\section{Conclusions}

Sustainability of general government debt of small open economy is one of the prerequisites for its sustainable economic growth. Accurate evaluation of the sustainability of general government debt is essential for the effective management of the general government's debt.

Borrowing of small open economy is subjected for relatively high borrowing risk in terms of its vulnerability to the stochastic changes of global economy and international borrowing markets. Therefore, borrowing strategy of such governments should be based on sustainable borrowing principles. Respectively, evaluation of the sustainability of general government's debt in small open economy should be based on estimation whether existing debt and borrowing strategy can be considered as oriented towards sustainable debt management. 
In terms of the size of economy, there is no significant impact of it on the ability to perform effective debt management. But size of the economy (in terms of its ability to influence global or regional economy) determines its level of vulnerability to unfavourable changes of international borrowing markets.

Considering small open economy's vulnerability to stochastic changes of economy, the priority should be given to evaluation methods that take the economic uncertainty (and its impact on the economy of the country) into the consideration.

The evaluation of general government's debt sustainability in stochastic economy requires focusing on the analysis of the contingency of economy. Furthermore, systematic approach should be applied to the evaluation of sustainability of the general government debt in order to keep the integrity of the evaluation of different contingent factors. The basis of the sustainability of a general government's debt should be complex analysis of the factors, influencing the debt sustainability. Such analysis must be based on the usage of stochastic methods.

Also, evaluation of sustainability of general government's debt should be performed from the long-run perspective. Debt sustainability monitoring system and trade-off between borrowing costs and benefit of the sustainable borrowing should be evaluated.

Regardless the methods (either qualitative or quantitative), used for the evaluation of the sustainability of general government's debt in small open economy, the evaluation must be performed considering specific economic situation of the country.

Sustainability of the general government's debt should be determined by its contribution to sustainability of the country's economy. Therefore, the same base should be used for the overall evaluation of the sustainability of general government's debt in a small open economy.

In the article, some results of evaluation of the sustainability of the general government's debt in a small open economy were presented, the example of Lithuania's general government's borrowing and debt management was used. In general, we assume that management of Lithuanias's general government debt is based on the relevant sustainability principles.

\section{References}

Aspromourgos, T., Rees, D, \& White, G. (2010). Public debt sustainability and alternative theories of interest. Cambridge Journal of economics, 34(3), 433-447.

Budina, N., \& Wijnbergen, S. (2009). Quantitative Approaches to Fiscal Sustainability Analysis: A Case Study of Turkey since the Crisis of 2001. World Bank Economic Review, 23(1), 119-140.

Choi, G.-H., Kim, M.-J., \& Lee, H. (2010). Assessing Sovereign Debt Strategies Under Alternative Term Structure Models. Asia-Pacific Journal of Financial Studies, 39(6), 777-779.

Ciegis, R., Ramanauskiene, J., \& Martinkus, B. (2009a). The Concept of Sustainable Development and its Use for Sustainability Scenarios. Inzinerine Ekonomika-Engineering Economics(2), 28-37.

Consiglio, A., \& Staino, A. (2012). A stochastic programming model for the optimal issuance of government bonds. Annals of Operations Research, 193(1), 159-172.

Date, P., Canepa, A., \& Abdel-jaward, M. (2011). A mixed integer linear programming model for optimal sovereign debt issuance. European Journal of Operational Reasearch, 214(3), 749-758.

Down, I. (2007). Trade Openess, Country Size and Economic Volatility: The Compensation Hypothesis Revisited. Business \& Politics, $9(2)$.

Edwards, S. (1993). Openness, Trade Liberalization, and Growth in Developing Countries. Journal of Economic Literature, 31(3).

Eggertsson, G. B., \& Krugman, P. (2012). Debt, Deleveraging, and the Liquidity Trap: A Fisher-Minsky-Koo Approack. Quarterly Journal of Economics, 127(3), 1469-1513.

Faraglia, E., Marcet, A., \& Oikonomou, R. (2013). The Impact of Debt Levels and Debt Maturity on Inflation. Economic Journal, 123(566), F164-F192.

Ferrarini, B. (2009). Policy, vulnerability and the New Debt Sustainability Framework. Journal of International Development, 21(7), 895914.

Ferrarini, B. (2008). Proposal for a Contingency Debt Sustainability Framework. World Development, 36(12), 2547-2565.

Frank, N., \& Ley, E. (2009). On the Probabilistic Approach to Fiscal Sustainability: Structural Breaks and Non-Normality. IMF Staff Papers, 56(4), 742-757.

Garcia, M, \& Rigobon, R. (2004). A Risk Management Approach to Emerging Market's Sovereign Debt Sustainability with an Application to Brazilian Data. NBER Working paper No. 10336, March.

Genberg, H., \& Sulatarova, A. (2008). Macroeconomic volatility, debt dynamics, and sovereign interest rate spreads. Journal or International Money and Finance, 27(1), 26-39.

Goldstein, J. (2010). Debt Sustainability Assessment: The IMF Approach and Alternatives. Retrieved 2010-05-06 from: http://www.aep2010.com/pdfs/3-16-10\%20Tuesday/Mesquite\%20Room/1_1030am-1145am/Goldstein\%20- 
\%202010\%20AEP\%20Annual\%20Meeting\%20FINAL\%20DRAFT\%20Presentation.pdf.

Hajdenberg, A., \& Romeu, R. (2010). Parameter Estimate Uncertainty in Probabilistic Debt Sustainability Analysis. IMF Staff Papers, 57(1), 61-83.

Izák, V. (2009). Primary Balance, Public Debt And Fiscal Variables In Postsocialist Members Of The European Union. Retrieved 201005-15 from http://ideas.repec.org/a/prg/jnlpep/v2009y2009i2id345p114-130.html

Karazijiene, Z. (2009). Modelling of the Effect of the Public Sector Borrowing on the Lithuanian Economy. Inzinerine EkonomikaEngineering Economics(4), 24-31.

Knedlik, T., \& Von Schweinitz, G. (2012). Macroeconomic Imbalances as Indicators for Debt Crises in Europe. JCMS-Journal of common market studies, 50(5), 726-745.

Legrenzi, G., \& Milas, C. (2012). Nonlinearities and the sustainability of the government's intertemporal budget constraint. Economic Inquiry, 50(4), 988-999.

Liliko, A., Holmse, E., \& Sameen, H. (2009). Controlling Spending and Government Deficits: Lessons from History and International Experience. Policy Exchange, November.

Mankiw, N. G. (1997). Macroeconomics. - New York: Worth Publishers.

Milne, A. K. L. (2011). Limited Liability Government Debt for the Eurozone. Cesifo Economic Studies, 57(1), 44-78.

Melecky, M. (2012). Choosing the currency structure of foreign-currency debt: a review of policy approaches. Journal of International Development, 24(2), 133-151.

Moinescu, B.-G. (2013). The lending channel and budget balance: empirical evidences from Central and Eastern European economies. Theoretical and Applied Economics, 3(580), 17-30.

Molănescu, G., \& Aceleanu, M. I. (2011). Consequences of the Budget Deficit in the Current Crisis in Romania. Implications on the Labor Market. Theoretical and Applied Economics, 02(555), 59-74.

Neck, R., \& Sturm, J.-E. (2009). Sustainability of public debt. Journal of Economics, 97(1), 95-96.

Pisani, M. (2011). Financial Openess and Macroeconomic Instability in Emerging Market Economies. Open Economies Review, 22(3), 501-532.

Presbitero, A. F., \& Arnone, M. (2006). External debt sustainability and domestic debt in Heavily Indebted Poor Countries. MPRA Paper 1396, University Library of Munich, Germany.

Public sector debt statistics: guide for compilers and users (2011). International Monetary Fund, 2011. Retrieved 2013-05-05 from http://www.tffs.org/pdf/method/PSDS11fultext.pdf

Raimondos-Moller, P., \& Woodland, A. D. (2000). Tariff Strategies and Small Open Economy. Canadian Journal of Economics, 33(1).

Rankin, N., \& Roffia, B. (1999). Maximum Sustainable Government Debt in the Overlapping Generations Model. The Warwick Economics Research Paper Series, 521.

Roubini, N., \& Bykere, A. (2010). The Coming Sovereign Debt Crisis. Retrieved 2013-06-02 from http://www.forbes.com/2010/01/13/ sovereign-debt-crisis-opinions-colummnists-nouriel-roubini-arpitha-bykere.html?feed=rss_opinions

Ryskulov, U, \& Mera, N. (2012). The Impact of Government Debt and Debt Servicing on Economic Growth: An Empirical Approach for Albania. Mediterranean Journal of Social Sciences, Special Issue, Vol. 3, No. 5, March, 265-275.

Sopek, P. (2009). The effect of the financial crisis on Croatia's primary budget deficit and public debt. Financial Theory and Practice, 33(3), 273-298

Statistical office of the European Union - Eurostat. Retrieved 2013-05-30 from http://epp.eurostat.ec.europa.eu/statistics_explained/ index.php/Structure of government debt\#General government

Taylor, L., Proano, Ch. R., de Carvalho, L., \& Barbosa, N. (2012). Fiscal deficits, economic growth and government debt in the USA. Cambridge Journal, 36(1), 189-204.

Tanner, E., \& Samake, I. (2008). Probabilistic sustainability of public debt: A vector autoregression approach for Brasil, Mexico, and Turkey. IMF Staff Papers, 55(1), 149-182.

Teica, R. A. (2012). Analysis of the public debt sustainability in the Economic and Monetary Union. International conference emerging markets queiries in finance and business, 3, 1081-1087.

Telatar, E., Bolatoglu, N., \& Telatar, F. (2004). A New Approach on Testing the Behaviour of the Government Towards Sustainability of Fiscal Policy in a Small-Open and Politically Instable Economy. Applied Economics Letters, 11(5), April.

Uctum, M., \& Wickens, M. (2000). Debt and Deficit Ceilings, and Sustainability of Fiscal Policy: an Intertemporal Analysis. Oxford Bulletin of Economics and Statistics, 62, 197-222.

Von Wijnbergen, S., \& France, A. (2012). Assessing Debt Sustainability in a Stochastic Environment: 200 Years of Dutch debt and Deficit management. Economist-Nederlands, 160(3), 219-236.

Wyplosz, Ch. (2007). Debt Sustainability Assessment: The IMF Approach and Alternatives. HEI Working Paper No. 03/2007. 